\title{
Performance and nitrogen balance of laying hens fed increasing levels of digestible lysine and arginine
}

\author{
Fabyola Barros de Carvalho', José Henrique Stringhini', Maíra Silva Matos ${ }^{1}$, Roberto Moraes \\ Jardim Filho', Marcos Barcellos Café', Nadja Susana Mogyca Leandro', Maria Auxiliadora \\ Andrade $^{1}$
}

${ }^{1}$ Departamento de Produção Animal, Escola de Veterinária e Zootecnia, UFG, Goiânia, GO, Brazil.

\begin{abstract}
The objective of this experiment was to evaluate the effect of two digestible lysine levels and four digestible arginine levels on laying hens from 24 to 48 weeks of age. Three hundred and twenty Lohmann LSL laying hens were allotted in a completely randomized design in a $2 \times 4$ factorial arrangement, with two levels of digestible lysine $(700 \mathrm{and} 900 \mathrm{mg} / \mathrm{kg}$ of diet) and four digestible arginine levels $(700,800,900$ and $1000 \mathrm{mg} / \mathrm{kg}$ of diet). Results indicated requirement of 884 and $830 \mathrm{mg}$ of digestible arginine $/ \mathrm{kg}$ of diet, considering an average feed intake of $95 \mathrm{~g} / \mathrm{hen} /$ day and an average hen weight of $1.5 \mathrm{~kg}$, aiming at lesser feed intake and better nutritional balance of nitrogen, respectively. High digestible lysine levels in the diet require higher digestible arginine supplementation for a better performance of hens.
\end{abstract}

Key Words: antagonism, digestibility, digestible amino acids, egg, production

\section{Introduction}

Modern hen diets have been formulated according to the requirements of crude protein, which may unbalance the levels of amino acids as well as the relation between them. The ingestion and metabolism of amino acids increases the temperature of the body (Musharaf \& Latshaw, 1999), uric acid excretion (Latshaw \& Zhao, 2011), energy waste (Leclercq, 1998), and water intake, which may result in aqueous feces, leading to performance problems (Emadi et al., 2010).

Modern diet formulas for laying hens must consider the concept of ideal protein, based on the amount of amino acids, which would be more efficiently used by the hens. For this reason, it is important to establish the relations between the amino acids that are better adapted to the digestion and absorption capacity of hens, reducing the necessity of spending excessive excretion of amino acids, thus saving body energy (Parsons \& Baker, 1994). The concept of ideal protein uses lysine as a reference amino acid due to its specific function in the animal organism, which is the protein deposition, and for the great amount of information about its concentration and digestibility (Parsons et al., 1992). Nevertheless, as the level of lysine is increased in diet, arginine becomes the limiting amino acid for the best hen performance. However, higher levels of lysine result in higher arginine requirements (Macari et al., 2002).
There is evidence of considerable antagonism between arginine and lysine (Austic \& Scott, 1975). One reason for this antagonism is the urinary losses of arginine, caused by the lysine competition for urinary tubular reabsorption (Macari et al., 2002). Because of this, it is important to find the correct adjustment of amino acid ratios for the development of ideal protein formulas, and the achievement of the best production efficiency (Gadelha et al., 2003; Silva et al., 2005).

In hens, only 35 to $45 \%$ of the nitrogen from the protein intake turns into meat and eggs. The rest of the nitrogen is excreted, and becomes a source of environmental contamination (Penz Junior, 1993). Synthetic amino acid supplementation in laying hen diets allows better protein utilization, contributing to a reduction of excreted nitrogen and, consequently, improvement in the performance of hens.

The objective of this experiment was to evaluate the ratios of lysine and arginine supplementation for commercial Lohmann LSL laying hens at the starter production phase, and their effect on performance and nutritional balance of nitrogen.

\section{Material and Methods}

The experiment was carried out at the poultry facilities of the Veterinary School of Universidade Federal de Goias, Brazil, from January to July, 2005. A total of 320 Lohmann 
LSL hens of 24 weeks of age were subjected to a performance trial. For the metabolic assays, 64 additional Lohmann LSL hens, at 34, 42 and 48 weeks of age, were used. The design was completely randomized, in a $2 \times 4$ factorial arrangement (digestible lysine vs. digestible arginine levels) with four replicates per treatment of 10 hens each.

A corn-soybean basal diet (Table 1) was formulated according to the feed composition and dietary requeriment, fulfilling the requirements established by Rostagno et al. (2000). In addition, $0.178 \%$ and $0.202 \%$ of L-lysine, as well as $0.0 ; 0.105 ; 0.211$ and 0.316 of L-arginine were added to the diet in order to meet the suggested levels of 700 and $900 \mathrm{mg}$ of digestible lysine/ $\mathrm{kg}$ of diet, and of 700, 800,900 and $1000 \mathrm{mg}$ of digestible arginine $/ \mathrm{kg}$ of diet, respectively.

At the end of each 28-day period, feed and nutrient intake, as well as the number of dead hens, were observed in order to correct consumption values. All the eggs produced were counted every day during all the experimental period, and the results were expressed in percentage. Feed conversion ( $\mathrm{kg} /$ dozen and $\mathrm{kg} / \mathrm{kg}$ egg mass) was obtained at each 28-day period. In the last three days of each period, 16 eggs per treatment per day were weighed and the egg mass was obtained.

Table 1 - Composition and nutritional value calculated as basal diet

\begin{tabular}{lc}
\hline Ingredient & $\mathrm{g} / \mathrm{kg}$ as fed \\
\hline Corn & 646 \\
Soybean meal 42\% & 97 \\
Wheat bran & 55 \\
Corn gluten $60 \%$ & 55 \\
Limestone & 90 \\
Meat meal & 40 \\
Salt & 0.039 \\
Mineral and vitamin supplementation ${ }^{1}$ & 0.012 \\
L-lysine $\mathrm{HCL}$ & 0.017 \\
L-arginine $\mathrm{HCl}$ & 0.000 \\
DL-methionine 99 & 0.016 \\
L-tryptophan & 0.007 \\
Starch & 0.061 \\
Metabolizable energy $(\mathrm{kcal} / \mathrm{kg})$ & 2,800 \\
Crude protein $(\mathrm{g} / \mathrm{kg})$ & 160 \\
Calcium $(\mathrm{g} / \mathrm{kg})$ & 40.5 \\
Available phosphorous $(\mathrm{g} / \mathrm{kg})$ & 3.8 \\
Lysine $(\mathrm{g} / \mathrm{kg})$ & 7.7 \\
Digestible $\mathrm{lysine}(\mathrm{g} / \mathrm{kg})$ & 7.0 \\
Arginine $(\mathrm{g} / \mathrm{kg})$ & 7.5 \\
Digestible arginine $(\mathrm{g} / \mathrm{kg})$ & 7.0 \\
Methionine + cystine $(\mathrm{g} / \mathrm{kg})$ & 6.9 \\
Methionine $(\mathrm{g} / \mathrm{kg})$ & 3.9 \\
Threonine $(\mathrm{g} / \mathrm{kg})$ & 5.9 \\
Tryptophan $(\mathrm{g} / \mathrm{kg})$ & 2.0 \\
Arginine:lysine & 1.00 \\
\hline
\end{tabular}

${ }^{1}$ Mineral and vitamin supplementation (composition/kg of feed): vit. A - 2,500,000 IU; vit. D3 - 625,000 IU; vit. E - 3,750 mg; vit. K3 - $500 \mathrm{mg}$; vit. B1 - $500 \mathrm{mg}$; vit. B2 - 1,000 mg; vit. B6 - 1,000 mg; vit. B12 - 3,750 mcg; niacin - 7,500 mg; acid pantothenate - 4,000 mg; biotin - $15 \mathrm{mg}$; folic acid $-125 \mathrm{mg}$; choline - 75,000 mg; selenium - $45 \mathrm{mg}$; iodine - $175 \mathrm{mg}$; iron - 12,525 mg; copper - 2,500 mg; manganese $19,500 \mathrm{mg}$; zinc - 13,750 mg; avilamycin - 20,000 mg.
Nitrogen balance was obtained during four days at 34, 42 and 48 weeks of age. Excreta was collected twice a day by the total excreta collection method, identified, stored and prepared for nitrogen analysis. The feed and the eggs weighed during the metabolic assay were used to calculate nitrogen balance and retention, expressed by milligrams of nitrogen per gram of egg mass produced.

Chemical analysis of diet and excreta were performed at the Laboratório de Nutrição Animal of Universidade Federal de Goias. Dry matter and total nitrogen were determined as proposed by Silva \& Queiroz (2002). Nitrogen balance (NB) was determined as follows:

$\mathrm{NB}(\mathrm{g})$ : ingested $\mathrm{N}-$ excreted $\mathrm{N}$;

$\mathrm{NB}(\mathrm{g} / \mathrm{g})=($ ingested $\mathrm{N}-$ excreted $\mathrm{N}) /$ ingested $\mathrm{N} *$ 100 and;

NB per egg mass $(\mathrm{mg} / \mathrm{g})=($ ingested $\mathrm{N}-$ excreted $\mathrm{N}) /$ egg mass * 100

Results were analyzed by ANOVA using SAEG (Sistema para Análises Estatísticas e Genéticas, version 7.1), and submitted to polynomial regression for the levels of digestible arginine tested.

\section{Results and Discussion}

Egg production, average egg weight, egg mass, feed conversion per gram of egg produced, and feed conversion per dozen egg produced were not affected (Table 2). On the other hand, feed intake, lysine intake and arginine intake showed significantly effect nutritional treatments.

Unlike the results obtained in this study, in which no difference was found for egg production and mass, regardless of the arginine:lysine ratio used, Araújo et al. (2005) tested six arginine:lysine diet levels (718:716; 790:716; 718:644; 790:644; 718:788; and 790:788) in 40week old Lohmann Brown and Lohmann LSL hens, and found that these two variables were higher when using an arginine:lysine level of $718: 716 \mathrm{mg}$, whereas the lowest egg weight was obtained with the 790:716 mg digestible lysine:arginine diet level.

Lima et al. (2007) worked with light and heavy hens fed two levels of digestible lysine $(710$ and $780 \mathrm{mg} / \mathrm{kg}$ of diet) and three levels of digestible arginine (640;720 and $790 \mathrm{mg} / \mathrm{kg}$ of diet), and found statistical interaction of egg production and feed conversion per egg mass. In their study, the best results were obtained with $710 \mathrm{mg}$ of digestible lysine and $790 \mathrm{mg}$ of digestible arginine $/ \mathrm{kg}$ of diet. Egg weight also showed to be affected, with the best results found at the lowest level of digestible lysine $(710 \mathrm{mg})$ and arginine $(640 \mathrm{mg})$ levels. 
Table 2 - Performance of laying hens fed increasing levels of digestible lysine and arginine/kg of diet from 24 to 44 weeks of age

\begin{tabular}{|c|c|c|c|c|c|c|c|c|}
\hline & $\begin{array}{c}\text { Egg production } \\
(\%)\end{array}$ & $\begin{array}{l}\text { Egg weight } \\
(\mathrm{g})\end{array}$ & $\begin{array}{l}\text { Egg mass } \\
(\mathrm{g})\end{array}$ & $\begin{array}{l}\text { Feed intake } \\
(\mathrm{g} / \mathrm{hen} / \text { day })\end{array}$ & $\begin{array}{l}\text { Lysine intake } \\
\text { (mg/hen/day) }\end{array}$ & $\begin{array}{l}\text { Arginine intake } \\
\text { (mg/hen/day) }\end{array}$ & $\begin{array}{l}\text { Feed conversion } \\
(\mathrm{kg} / \mathrm{kg} \text { eggs })\end{array}$ & $\begin{array}{r}\text { Feed conversion } \\
\text { (kg/dozen eggs) }\end{array}$ \\
\hline \multicolumn{9}{|c|}{ Lysine (mg/kg of diet) } \\
\hline 700 & 90.16 & 58.84 & 52.97 & 94.78 & 663.51 & 783.42 & 1.793 & 1.265 \\
\hline 900 & 90.59 & 58.59 & 53.17 & 94.60 & 851.45 & 811.00 & 1.787 & 1.254 \\
\hline \multicolumn{9}{|c|}{ Arginine (mg/kg of diet) } \\
\hline 700 & 89.74 & 58.90 & 52.85 & 95.00 & 762.09 & 681.18 & 1.802 & 1.272 \\
\hline 1000 & 91.50 & 58.76 & 53.82 & 95.77 & 765.49 & 925.73 & 1.787 & 1.260 \\
\hline \multicolumn{9}{|c|}{$P$ value } \\
\hline Lysine & 0.728 & 0.560 & 0.818 & 0.828 & 0.001 & 0.001 & 0.819 & 0.547 \\
\hline Arginine & 0.623 & 0.881 & 0.654 & 0.353 & 0.253 & 0.001 & 0.664 & 0.616 \\
\hline Lysine $\times$ arginine & 0.409 & 0.793 & 0.729 & 0.004 & 0.003 & 0.006 & 0.118 & 0.078 \\
\hline
\end{tabular}

$\mathrm{CV}(\%)$ - coefficient of variation.

There was significant interaction $(\mathrm{P}<0.05)$ between the levels of digestible lysine and arginine for feed intake (Table 3). For the diet with $700 \mathrm{mg}$ of digestible arginine $/ \mathrm{kg}$, there was lower feed intake the hens at the level of $700 \mathrm{mg}$ of digestible lysine than at $900 \mathrm{mg} / \mathrm{kg}$ of diet. When the arginine level was incremented up to $900 \mathrm{mg} / \mathrm{kg}$ of diet, opposite results were observed.

Lysine intake (Table 3) occurred as expected, considering that the hens that were fed $900 \mathrm{mg}$ of lysine/ $\mathrm{kg}$ of diet presented higher lysine intake when compared with the ones that were fed $700 \mathrm{mg}$ of lysine $/ \mathrm{kg}$ of diet. As regards arginine intake, the only difference observed occurred with diets at the levels of 700 and $800 \mathrm{mg}$ of arginine $/ \mathrm{kg}$ of diet, with higher arginine intake for hens

Table 3 - Effect of interaction for laying hens fed increasing levels $(\mathrm{mg} / \mathrm{kg}$ of diet) of digestible lysine and arginine from 24 to 44 weeks of age

\begin{tabular}{lcccccc}
\hline \multicolumn{7}{c}{ Arginine } \\
\hline Lysine & 700 & 800 & 900 & 1000 & P value & CV \% \\
700 & $92.91 \mathrm{~b}$ & 93.49 & $96.25 \mathrm{a}$ & 96.51 & 0.117 & 2.5 \\
900 & $97.10 \mathrm{a}$ & 95.05 & $91.24 \mathrm{~b}$ & 95.04 & $0.024^{1}$ & 2.4 \\
\multicolumn{7}{c}{ Lysine intake (mg/hen/day) } \\
700 & $650.34 \mathrm{~b}$ & $654.42 \mathrm{~b}$ & $673.72 \mathrm{~b}$ & $675.60 \mathrm{~b}$ & 0.117 & 2.5 \\
900 & $873.86 \mathrm{a}$ & $855.42 \mathrm{a}$ & $821.17 \mathrm{a}$ & $855.38 \mathrm{a}$ & $0.024^{2}$ & 2.4 \\
& & Arginine intake (mg/hen/day) & & \\
700 & $650.34 \mathrm{~b}$ & $732.32 \mathrm{~b}$ & 834.13 & 916.89 & $0.001^{3}$ & 2.4 \\
900 & $712.03 \mathrm{a}$ & $776.22 \mathrm{a}$ & 821.17 & 934.58 & $0.001^{4}$ & 2.6 \\
\hline
\end{tabular}

Different letters in the column differ $(0.05)$ by the $\mathrm{F}$ test.

$\mathrm{CV}$ - coefficient of variation.

${ }^{1} 900 / \mathrm{Y}=206.885-0.258520+0.000146209 \mathrm{X}^{2} / \mathrm{R}^{2}=0.76 /$ Minimum $=884 \mathrm{mg}$

$2900 / \mathrm{Y}=1861.97-2.32668 \mathrm{X}+0.00131588 \mathrm{X}^{2} / \mathrm{R}^{2}=0.76 /$ Minimum $=884 \mathrm{mg}$.

${ }^{3} 700 / \mathrm{Y}=17.1690+0.901471 \mathrm{X} / \mathrm{R}^{2}=1.00$.

${ }^{4} 900 / \mathrm{Y}=205.296+0.712594 \mathrm{X} / \mathrm{R}^{2}=0.96$ that received $900 \mathrm{mg}$ of digestible lysine/ $\mathrm{kg}$ of diet than the ones that received $700 \mathrm{mg}$.

Responses to the increasing levels of digestible arginine $/ \mathrm{kg}$ of diet showed a quadratic effect for the consumption of feed and digestible lysine for hens fed diets with $900 \mathrm{mg}$ of digestible lysine $/ \mathrm{kg}$ of diet (Table 3), whereas digestible arginine intake showed expected linear increase as the levels of digestible arginine per $\mathrm{kg} / \mathrm{diet}$ were increased from $700 \mathrm{mg}$ to $1000 \mathrm{mg}$ at the two levels of digestible lysine tested. On the other hand, Araújo et al. (2005), in a study previously mentioned, did not find differences for feed intake. In a similar study with the same hen lineages, Lima et al. (2005) also did not find changes.

The reduction in lysine intake observed with digestible arginine supplementation, when high levels of digestible lysine are adopted, can be explained by the antagonistic relationship between these two amino acids. As both amino acids use the same renal tubular transportation system, lysine and arginine compete for renal re-absorption. This may cause arginine loss through the urine, and may decrease hepatic transaminase activity due to excessive lysine (Macari et al., 2002). Increase in arginine consumption confirms the suggestion by Leeson \& Summers (2001), in which absence of a functional urea cycle requires arginine supply in the diet. The more lysine is added to the diet, the more arginine is required.

The levels of digestible arginine in diets fed to 34week old hens did not produce any changes in the nitrogen balance in grams, percentage, or per egg mass, in its intake or excretion (Table 4). Nitrogen intake was higher $(\mathrm{P}<0.05)$ in hens fed $900 \mathrm{mg}$ digestible lysine $/ \mathrm{kg}$ of diet. 
Rizzo et al. (2004) did not find differences in nitrogen intake, excretion and balance in the diet supplemented with 850 and $1000 \mathrm{mg}$ of digestible lysine and fed to 51-week old Hisex White hens. When metabolic assays were conducted with 42-week old animals, statistical interaction was found between the two amino acids, for all the variables studied $(\mathrm{P}<0.05)$ (Table 5).

Hens fed supplementation with $1000 \mathrm{mg}$ of digestible arginine (Table 6) showed higher nitrogen balance in $\mathrm{g}$, in percentage, and per egg mass when $900 \mathrm{mg}$ of digestible lysine were used $(\mathrm{P}<0.05)$. The same was not seen for the other supplementation levels of arginine $/ \mathrm{kg}$ of the diet. Increase of arginine in the diet with $700 \mathrm{mg}$ of digestible

Table 4 - Nitrogen metabolism of laying hens fed increasing levels of digestible lysine and arginine $/ \mathrm{kg}$ of diet at 34 weeks of age

\begin{tabular}{lccccc}
\hline & $\begin{array}{c}\text { N balance } \\
(\mathrm{g})\end{array}$ & $\begin{array}{c}\mathrm{N} \text { balance } \\
(\mathrm{g} / \mathrm{g} \text { DM })\end{array}$ & $\begin{array}{c}\text { N balance } \\
\text { per egg mass } \\
(\mathrm{mg} / \mathrm{g})\end{array}$ & $\begin{array}{c}\mathrm{N} \text { intake } \\
(\mathrm{g})\end{array}$ & $\begin{array}{c}\mathrm{N} \\
\text { excretion } \\
(\mathrm{g})\end{array}$ \\
\hline \multicolumn{5}{c}{ Lysine $(\mathrm{mg} / \mathrm{kg}$ of diet $)$} \\
700 & 7.24 & 0.403 & 19.00 & $17.84 \mathrm{~b}$ & 10.60 \\
900 & 7.76 & 0.404 & 19.76 & $19.20 \mathrm{a}$ & 11.43 \\
& \multicolumn{5}{c}{ Arginine (mg/kg of diet) } \\
700 & 6.91 & 0.392 & 17.22 & 17.57 & 10.75 \\
800 & 7.52 & 0.406 & 19.68 & 18.56 & 11.03 \\
900 & 7.75 & 0.398 & 20.39 & 19.11 & 11.35 \\
1000 & 7.81 & 0.417 & 20.22 & 18.73 & 10.92 \\
& \multicolumn{5}{c}{ P value } \\
Lysine & 0.356 & 0.964 & 0.646 & 0.029 & 0.133 \\
Arginine & 0.660 & 0.905 & 0.496 & 0.376 & 0.879 \\
Lys $\times$ arg & 0.853 & 0.926 & 0.658 & 0.772 & 0.907 \\
CV $(\%)$ & 21.1 & 17.9 & 23.7 & 9.0 & 13.7 \\
\hline
\end{tabular}

Different letters in the column differ by the $\mathrm{F}$ test $(0.05)$.

$\mathrm{CV}$ - coefficient of variation; DM - dry matter.

Table 5 - Nitrogen metabolism of laying hens fed increasing levels of digestible lysine and arginine $/ \mathrm{kg}$ of diet at 42 weeks of age

$\mathrm{N}$ balance $\mathrm{N}$ balance $\mathrm{N}$ balance $\mathrm{N}$ intake $\mathrm{N}$

(g) $\quad(\mathrm{g} / \mathrm{g} \mathrm{DM})$ per egg mass $(\mathrm{g})$ excretion

$(\mathrm{mg} / \mathrm{g})$

(g)

\begin{tabular}{lccccc}
\hline \multicolumn{5}{c}{ Lysine (mg/kg of diet) } \\
700 & 4.29 & 0.394 & 17.61 & 10.80 & 6.50 \\
900 & 4.54 & 0.408 & 19.60 & 10.91 & 5.37 \\
& \multicolumn{5}{c}{ Arginine (mg/kg of diet) } \\
700 & 3.52 & 0.364 & 13.57 & 9.55 & 5.12 \\
800 & 4.01 & 0.376 & 17.97 & 10.51 & 5.50 \\
900 & 5.47 & 0.454 & 23.73 & 11.99 & 5.52 \\
1000 & 4.67 & 0.410 & 19.17 & 11.17 & 5.50 \\
& 0.401 & 0.479 & 0.301 & 0.682 & 0.544 \\
Lysine & 0.007 & 0.078 & 0.054 & 0.001 & 0.411 \\
Arginine & 0.001 & 0.001 & 0.001 & 0.018 & 0.021 \\
Lys $\times$ Arg & 0.001 & P value \\
CV (\%) & 18.7 & 14.4 & 28.6 & 7.4 & 9.4 \\
\hline
\end{tabular}

$\mathrm{CV}$ - coefficient of variation; DM - dry matter. lysine resulted in a quadratic effect $(\mathrm{P}<0.05)$ for nitrogen balance in grams, with a peak at the level of $844 \mathrm{mg}$ of digestible arginine/kg in diet. Linear effect for nitrogen balance in grams, in percentage, and per egg mass was observed at the level of $900 \mathrm{mg}$ of lysine.

When hens are fed diets containing excessive levels of either arginine or lysine, the activity of the enzyme arginase increases. Therefore, little excess of lysine in the diet may increase arginine degradation (Leeson \& Summers, 2001). This antagonistic relationship may explain the increase seen in nitrogen balance in grams, in percentage, and per egg mass when the level of digestible arginine is increased in the diet.

Higher nitrogen intake was observed in the diet containing $900 \mathrm{mg}$ of digestible lysine and $1000 \mathrm{mg}$ of digestible arginine (Table 7); however, this did not occur for nitrogen excretion. A quadratic effect was observed for

Table 6 - Effect of interaction for laying hens fed increasing levels of digestible lysine $(\mathrm{mg} / \mathrm{kg}$ of diet) and arginine $(\mathrm{mg} / \mathrm{kg}$ of diet) at 42 weeks of age

\begin{tabular}{lcccccc}
\hline \multicolumn{7}{c}{ Arginine } \\
\hline \multicolumn{7}{c}{ Nitrogen balance (g) } \\
Lysine & 700 & 800 & 900 & 1000 & P value & $\mathrm{CV}(\%)$ \\
700 & 3.99 & 4.38 & 5.43 & $3.37 \mathrm{~b}$ & $0.028^{1}$ & 19.5 \\
900 & 3.05 & 3.64 & 5.50 & $5.97 \mathrm{a}$ & $0.001^{2}$ & 17.9 \\
\multicolumn{7}{c}{} \\
Lysine & 700 & 800 & 900 & 1000 & P value & $\mathrm{CV}(\%)$ \\
700 & 0.401 & 0.410 & 0.437 & $0.326 \mathrm{~b}$ & 0.076 & 14.1 \\
900 & 0.326 & 0.341 & 0.471 & $0.495 \mathrm{a}$ & $0.002^{3}$ & 14.7 \\
& \multicolumn{7}{c}{ Nitrogen balance per egg mass (mg/g) } & \\
Lysine & 700 & 800 & 900 & 1000 & P value & $\mathrm{CV}(\%)$ \\
700 & 15.71 & 19.96 & 22.25 & $12.53 \mathrm{~b}$ & 0.100 & 30.6 \\
900 & 11.43 & 15.97 & 25.21 & $25.81 \mathrm{a}$ & $0.005^{4}$ & 26.9 \\
\hline
\end{tabular}

Different letters in the column differ by the $\mathrm{F}$ test $(0.05)$.

$\mathrm{CV}$ - coefficient of variation; DM - dry matter.

${ }^{1} 700 / \mathrm{Y}=-38.6547+0.103682 \mathrm{X}-0.0000614676 \mathrm{X}^{2} / \mathrm{R}^{2}=0.68 /$ Maximum $=844 \mathrm{mg}$.

$2900 / \mathrm{Y}=-4.46877+0.0106047 \mathrm{X} / \mathrm{R}^{2}=0.94$

${ }^{3} 900 / \mathrm{Y}=-13.2713+0.0637081 \mathrm{X} / \mathrm{R}^{2}=0.89$

${ }^{4} 900 / \mathrm{Y}=-24.9060+0.0523690 \mathrm{X} / \mathrm{R}^{2}=0.91$

Table 7 - Effect of interaction for laying hens fed increasing levels $(\mathrm{mg} / \mathrm{kg}$ of diet) of digestible lysine and arginine at 42 weeks of age

\begin{tabular}{lcccccc}
\hline \multicolumn{7}{c}{ Arginine } \\
\hline \multicolumn{7}{c}{ Nitrogen intake (g) } \\
Lysine & 700 & 800 & 900 & 1000 & P value & CV (\%) \\
700 & 9.89 & 10.61 & 12.38 & $10.29 \mathrm{~b}$ & $0.015^{1}$ & 8.9 \\
900 & 9.40 & 10.61 & 11.59 & $12.06 \mathrm{a}$ & $0.001^{2}$ & 5.6 \\
\multicolumn{7}{c}{ Nitrogen excretion (g) } \\
Lysine & 700 & 800 & 900 & 1000 & P value & CV (\%) \\
700 & 5.90 & 6.22 & 6.95 & 6.92 & 0.080 & 9.4 \\
900 & 6.34 & 6.97 & 6.08 & 6.08 & 0.080 & 9.3 \\
\hline
\end{tabular}

Different letters in the column differ by the $\mathrm{F}$ test $(0.05)$.

$\mathrm{CV}$ - coefficient of variation.

${ }^{1} 700 / \mathrm{Y}=-41.5174+0.122195 \mathrm{X}-0.0000701345 \mathrm{X}^{2} / \mathrm{R}^{2}=0.66 /$ Maximum $871 \mathrm{mg}$

$2900 / \mathrm{Y}=3.30866+0.00895178 \mathrm{X} / \mathrm{R}^{2}=0.97$ 
nitrogen intake $(\mathrm{P}<0.05)$, for supplementation levels of digestible arginine in a diet with $700 \mathrm{mg}$ of digestible lysine $/ \mathrm{kg}$. There was a peak at the level of $871 \mathrm{mg}$ of digestible arginine. Positive linear effect $(\mathrm{P}<0.05)$ was observed for hens fed $900 \mathrm{mg}$ of digestible lysine/kg of diet. The same was not observed for nitrogen excretion.

Adding arginine when using $900 \mathrm{mg}$ of digestible lysine resulted in an increase of nitrogen intake, but with no changes in nitrogen excretion. This result may be related to a greater biosynthesis of the nitric oxide, which is an arginine precursor (Bacila, 2003).

When hens reached 48 weeks of age, a statistical interaction $(\mathrm{P}<0.05)$ was found for levels of digestible lysine and arginine (Table 8). Supplementation with $800 \mathrm{mg}$ of digestible arginine (Table 9) showed greater nitrogen balance in grams, in percentage and per egg mass for $700 \mathrm{mg}$ of digestible lysine $(\mathrm{P}<0.05)$. However, when using $1000 \mathrm{mg}$ of digestible arginine, nitrogen balance values in percentage and per egg mass were greater for $900 \mathrm{mg}$ of digestible lysine $/ \mathrm{kg}$ of diet.

Adding arginine to the diet containing $700 \mathrm{mg}$ of digestible lysine resulted in a quadratic effect $(\mathrm{P}<0.05)$ for nitrogen balance in grams, in percentage and per egg mass, with peaks at the level of 821,786 and $814 \mathrm{mg}$ of digestible arginine/kg of diet, respectively (Table 9). No regression effect occurred for $900 \mathrm{mg}$ of digestible lysine $/ \mathrm{kg}$ of diet for the variables studied.

These values are similar to the $838 \mathrm{mg}$ arginine $/ \mathrm{kg}$ of diet suggested as the minimum amount required for digestible arginine for light hens fed $95 \mathrm{~g}$ of diet/hen/day and with average weight of $1.479 \mathrm{~kg}$ (Rostagno et al., 2005).

Table 8 - Nitrogen metabolism of laying hens fed increasing levels of digestible lysine and arginine $/ \mathrm{kg}$ of diet at 48 weeks of age

\begin{tabular}{|c|c|c|c|c|c|}
\hline & $\begin{array}{c}\mathrm{N} \text { balance } \\
(\mathrm{g})\end{array}$ & $\begin{array}{l}\text { N balance } \\
(\mathrm{g} / \mathrm{g} \mathrm{DM})\end{array}$ & $\begin{array}{c}\mathrm{N} \text { balance } \\
\text { per egg mass } \\
(\mathrm{mg} / \mathrm{g})\end{array}$ & $\begin{array}{c}\mathrm{N} \text { intake } \\
(\mathrm{g})\end{array}$ & $\begin{array}{c}\mathrm{N} \\
\text { excretion } \\
(\mathrm{g})\end{array}$ \\
\hline \multicolumn{6}{|c|}{ Lysine ( $\mathrm{mg} / \mathrm{kg}$ of diet) } \\
\hline 700 & 6.47 & 0.448 & 22.61 & 14.38 & 7.90 \\
\hline 900 & 6.22 & 0.435 & 20.90 & 14.26 & 8.04 \\
\hline \multicolumn{6}{|c|}{ Arginine ( $\mathrm{mg} / \mathrm{kg}$ of diet) } \\
\hline 700 & 6.55 & 0.465 & 21.92 & 14.07 & 7.52 \\
\hline 800 & 6.72 & 0.456 & 23.22 & 14.60 & 7.88 \\
\hline 900 & 6.20 & 0.422 & 21.27 & 14.63 & 8.43 \\
\hline 1000 & 5.90 & 0.423 & 20.60 & 13.97 & 8.07 \\
\hline \multicolumn{6}{|c|}{$P$ value } \\
\hline Lysine & 0.432 & 0.473 & 0.228 & 0.716 & 0.669 \\
\hline Arginine & 0.287 & 0.260 & 0.591 & 0.340 & 0.238 \\
\hline Lys $\times$ Arg & 0.001 & 0.002 & 0.001 & 0.014 & 0.037 \\
\hline $\mathrm{CV}(\%)$ & 14.0 & 11.9 & 18.1 & 6.3 & 11.0 \\
\hline
\end{tabular}

$\mathrm{CV}$ - coefficient of variation; DM - dry matter.
The values found for nitrogen balance (Table 9) showed higher supplementation levels of digestible arginine $/ \mathrm{kg}$ of diet (786 and $826 \mathrm{mg}$ ) for $700 \mathrm{mg}$ of digestible lysine. It is must be emphasized that the recommendation above was found based on an average intake of $95 \mathrm{~g} / \mathrm{hen} /$ day for light hens with average weight of $1500 \mathrm{~g}$. To improve hen performance, higher levels of digestible lysine should be accompanied by supplementation of digestible arginine.

For $700 \mathrm{mg}$ of digestible arginine (Table 10), there was lower consumption of nitrogen for $700 \mathrm{mg}$ of digestible lysine, if compared with $900 \mathrm{mg}(\mathrm{P}<0.05)$. The opposite was seen for $800 \mathrm{mg}$ of digestible arginine in the diet. When supplementation of $1000 \mathrm{mg}$ of digestible arginine was used, greater excretion of nitrogen was seen for the lowest level of digestible lysine (700 vs. 900). Supplementation of digestible arginine with $700 \mathrm{mg}$ of digestible lysine $/ \mathrm{kg}$

Table 9 - Effect of interaction for laying hens fed increasing levels $(\mathrm{mg} / \mathrm{kg}$ of diet $)$ of digestible lysine and arginine at 48 weeks of age

\begin{tabular}{lcccccc}
\hline \multicolumn{7}{c}{ Arginine } \\
\hline \multicolumn{7}{c}{ Nitrogen balance $(\mathrm{g})$} \\
Lysine & 700 & 800 & 900 & 1000 & P value & CV $(\%)$ \\
700 & 6.16 & $8.05 \mathrm{a}$ & 6.39 & 5.28 & $0.001^{1}$ & 9.2 \\
900 & 6.93 & $5.39 \mathrm{~b}$ & 6.01 & 6.53 & 0.276 & 17.8 \\
\multicolumn{7}{c}{ Nitrogen balance $(\mathrm{g} / \mathrm{g} \mathrm{DM})$} \\
Lysine & 700 & 800 & 900 & 1000 & P value & $\mathrm{CV}(\%)$ \\
700 & 0.465 & $0.521 \mathrm{a}$ & 0.432 & $0.375 \mathrm{~b}$ & $0.001^{2}$ & 8.2 \\
900 & 0.466 & $0.390 \mathrm{~b}$ & 0.413 & $0.471 \mathrm{a}$ & 0.266 & 14.9 \\
700 & 22.63 & $27.79 \mathrm{a}$ & 23.91 & $16.13 \mathrm{~b}$ & $0.001^{3}$ & 12.4 \\
Lysine & 700 & 800 & 900 & 1000 & P value & CV $(\%)$ \\
900 & 21.22 & $18.66 \mathrm{~b}$ & 18.64 & $25.06 \mathrm{a}$ & 0.242 & 23.0 \\
\hline
\end{tabular}

Different letters in the column differ by the $\mathrm{F}$ test $(0.05)$.

$\mathrm{CV}$ - coefficient of variation; DM - dry matter.

${ }^{1} 700 / \mathrm{Y}=-43.0902+0.123127 \mathrm{X}-0.0000749602 \mathrm{X}^{2} / \mathrm{R}^{2}=0.79 /$ Maximum $821 \mathrm{mg}$

${ }^{2} 700 / \mathrm{Y}=-125.684+0.445692 \mathrm{X}-0.000283354 \mathrm{X}^{2} / \mathrm{R}^{2}=0.86 /$ Maximum $786 \mathrm{mg}$.

$3700 / \mathrm{Y}=-187.133+0.526401 \mathrm{X}-0.000323387 \mathrm{X}^{2} / \mathrm{R}^{2}=0.98 /$ Maximum $814 \mathrm{mg}$.

Table 10 - Effect of interaction for laying hens fed increasing levels ( $\mathrm{mg} / \mathrm{kg}$ of diet) of digestible lysine and arginine at 48 weeks of age

\begin{tabular}{lcccccc}
\hline \multicolumn{7}{c}{ Arginine } \\
\hline \multicolumn{7}{c}{ Nitrogen intake (g) } \\
Lysine & 700 & 800 & 900 & 1.000 & P value & CV (\%) \\
700 & $13.27 \mathrm{~b}$ & $15.41 \mathrm{a}$ & 14.75 & 14.08 & $0.002^{1}$ & 4.4 \\
900 & $14.86 \mathrm{a}$ & $13.79 \mathrm{~b}$ & 14.51 & 13.87 & 0.466 & 7.7 \\
\multicolumn{7}{c}{ Nitrogen excretion (g) } \\
Lysine & 700 & 800 & 900 & 1.000 & P value & $\mathrm{CV}(\%)$ \\
700 & 7.11 & 7.36 & 8.36 & $8.79 \mathrm{a}$ & $0.010^{2}$ & 8.4 \\
900 & 7.92 & 8.39 & 8.50 & $7.34 \mathrm{~b}$ & 0.415 & 13.0 \\
\hline
\end{tabular}

Different letters in the column differ by the F test $(0.05)$.

$\mathrm{CV}$ - coefficient of variation.

${ }^{1} 700 / \mathrm{Y}=-36.9625+0.121118 \mathrm{X}-0.0000702136 \mathrm{X}^{2} / \mathrm{R}^{2}=0.85 /$ Maximum $862 \mathrm{mg}$.

$2700 / \mathrm{Y}=2.75763+0.00606073 \mathrm{X} / \mathrm{R}^{2}=0.95$. 
generated a quadratic effect $(\mathrm{P}<0.05)$ with a peak at the level of $862 \mathrm{mg}$ of digestible arginine. As for excretion, a linear effect was generated $(\mathrm{P}<0.05)$, with no difference for $900 \mathrm{mg}$ of digestible lysine in the nitrogen intake or excretion.

For $700 \mathrm{mg}$ of digestible lysine $/ \mathrm{kg}$ of diet, nitrogen intake was maximum with $862 \mathrm{mg}$ of digestible arginine, whereas greater nitrogen excretion was obtained with $1000 \mathrm{mg}$ of digestible arginine, which is probably related to the balance of amino acids in the diet (Table 10).

\section{Conclusions}

As lysine is added to the diet, more arginine is required. Therefore, to improve performance of the hens and optimize nitrogen metabolism, increase in the levels of digestible lysine should be accompanied by digestible arginine supplementation.

\section{References}

ARAUJO, D.M.; VILAR DA SILVA, J.H.; LIMA, M.R. et al. Níveis de lisina e arginina digestível para poedeiras no pico de postura. In: CONFERÊNCIA APINCO DE CIÊNCIA E TECNOLOGIA AVÍCOLAS, 7., 2005, Santos. Anais... Campinas: FACTA, 2005. p.136.

AUSTIC R.E.; NESHEIM, M.C. Arginine, ornithine and proline metabolism of chicks: Influence of diet and heredity. Journal of Nutrition, v.101, p.1403-1414, 1971. Available at: <http:// jn.nutrition.org/content/101/10/1403.full.pdf + html $>$ Accessed on: July 6, 2011.

AUSTIC, R.E.; SCOTT, R.L. Involvement of food intake in the lysine-arginine antagonism in chicks. Journal of Nutrition, v.105, p.1122-1131，1975. Available at: <http://jn.nutrition.org/ content/105/9/1122.full.pdf> Accessed on: July 6, 2011.

BLOCH, K.[1946] The metabolism of $1(+)$-arginine and synthesis of creatine in the pigeon. Journal of Biological Chemistry, v.165, p.477-484, 1946

BACILA, M. Bioquímica veterinária. 2.ed. São Paulo: ROBE, 2003. p.583.

COON, C. Amino acid requirement of commercial laying hens. In: ASIAN PACIFIC POULTRY CONGRESS, 6., 1998, Nagoya. Proceedings... Nagoya: Japan Poultry Science Association, 1998. p.70-75.

EMADI, M.; KAVEH, K.; BEJO, M.H. et al. Growth performance and blood parameters as influenced by different levels of dietary arginine in broiler chickens. Journal of Animal and Veterinary Advances, v.9, p.70-74, 2010.

GADELHA, A.C.; DAHLKE, F.; FARIA FILHO, D.E. et al. Interação entre arginina e lisina altera as respostas produtivas e a incidência de problemas de pernas em frangos de corte. In: CONFERÊNCIA
APINCO DE CIÊNCIA E TECNOLOGIA AVÍCOLAS, 5., 2003, Campinas. Anais... Campinas: FACTA, 2003. p.75.

LATSHAW, J.D.; ZHAO, L. Dietary protein effects on hen performance and nitrogen excretion. Poultry Science, v.90, p.99-106, 2011.

LECLERCQ, B. Specific effects of lysine on broiler production: comparison with threonine and valine. Poultry Science, v.77, p.118-123, 1998.

LEESON, S.; SUMMERS, J.D. Nutrition of the chicken. Guelph, Canadá: Department of Animal \& Poultry Science, University of Guelph. 2001. p.591.

LEHNINGER, A.L.; NELSON, D.L.; COX, M.M. Princípios de bioquímica. 2.ed. São Paulo: SARVIER, 1995. p.839.

LIMA, M.R.; VILAR DA SILVA, J.H. Efeito da relação lisina:arginina digestível sobre o desempenho de poedeiras comerciais no período de postura. Acta Veterinária Brasílica, v.1, p.118-124, 2007.

LIMA, M.R.; VILAR DA SILVA, J.H.; ROCHA, J.K.P. et al. Relações lisina e arginina digestíveis para poedeiras leves e semipesadas no pós-pico de postura. In: REUNIÃO ANUAL DA SOCIEDADE BRASILEIRA DE ZOOTECNIA, 42., 2005, Goiânia. Anais... Goiânia: SBZ, 2005. (CD-ROM).

MACARI. M.; FURLAN, R.L.; GONZALES, E. Fisiologia aviária aplicada a frangos de corte. Jaboticabal: FUNEP/UNESP, 2002. $375 \mathrm{p}$.

MUSHARAF, N.A.; LATSHAW, J.D. Heat increment as aff ected by protein and amino acid nutrition. World's Poultry Science Journal, v.55, p.233-240, 1999.

NATIONAL RESEARCH COUNCIL - NRC. Nutrient requirements of poultry. 9.ed. Washington D.C.: National Academic Press, 1994. $155 \mathrm{p}$.

NUNES, I.J. Nutrição animal básica. Proteínas. 2.ed. Belo Horizonte: FEP-MVZ, 1998. p.99-119.

PARSONS, C.M.; KOELKBECK, K.W.; LEEPER, R.W. et al. Effect of duration of fasting on post molt laying hen performance. Poultry Science, v.71, p.434-439, 1992.

PARSONS, M.C.; BAKER, D.H.The concept and use of ideal proteins in feeding of nonruminants, In: SIMPÓSIO INTERNACIONAL DE PRODUÇÃO DE NÃO-RUMINANTES, 31., 1994, Maringá. Anais... Maringá: SBZ, 1994. p.119.

PENZ JUNIOR, A.M. Digestibilidad de aminoácidos. In: SIMPÓSIO DE AVANCES TECNOLÓGICOS, 1993, República Dominicana. Anais... República Dominicana: NOVUS, 1993. p.35-48.

RIZZO, M.F.; ROMBOLA, L.G.; FARIA, D.E. et al. Alimentação de poedeiras com diferentes níveis de proteína e lisina: 1.utilização e excreção de nitrogênio. In: CONFERÊNCIA APINCO DE CIÊNCIA E TECNOLOGIA AVÍCOLAS, 6., 2004, Santos. Anais... Santos: FACTA, 2004. p.27.

ROSTAGNO, H.S.; ALBINO, L.F.T.; DONZELE, J.L. et al. Tabelas brasileiras para aves e suínos. Composição de alimentos e exigências nutricionais. Viçosa, MG: Editora UFV, 2005. 185p.

ROSTAGNO, H.S.; ALBINO, L.F.T.; DONZELE, J.L. et al. Tabelas brasileiras para aves e suínos. Composição de alimentos e exigências nutricionais de aves e suínos: tabelas brasileiras. Viçosa, MG: UFV, 2000. 141p.

SILVA, J.H.V.; JORDÃO FILHO J.; SILVA E.L. et al. Por que formular dietas para poedeiras com base no conceito de proteína ideal? Revista Ave World, v.3, p.50-57, 2005.

SILVA, D.J.; QUEIROZ, A.C. Análise de alimentos: métodos químicos e biológicos. 3.ed. Viçosa, MG: Editora UFV, 2002. 235p. 